\title{
Examination of the code requirements for the inter-story drift ratio limits
}

\author{
Özgür Avşar *iD \\ Eskişehir Technical University, Department of Civil Engineering, Eskişehir, Turkey
}

\begin{abstract}
Seismic design codes limit the inter-story drifts of buildings to protect the non-structural components and to minimize the secondary effects of gravity loads. A new version of Turkish Building Earthquake Code (TBEC, 2018) is in act starting from 2019 by replacing the former version of the Turkish Earthquake Code (TEC, 2007). One of the significant changes in TBEC (2018) is the definition of the inter-story drift ratio (ISDR) limit. The ISDR is limited by $2 \%$ as per TEC (2007) without considering any other criteria. However, the ISDR limit of TBEC (2018) is modified by considering several parameters. The type of building (reinforced concrete (RC) or steel), the interaction of infill walls with the neighbouring structural components and the ratio of spectral ordinates at the fundamental period of the building of 72-year return period earthquake to 475-year return period earthquake $(\lambda)$ are the three important parameters. Moreover, effective rigidities of RC members should be adopted in TBEC (2018). Change in ISDR demands and corresponding limits specified by the two versions of the earthquake code are examined for a 6-story RC building. Moreover, the variation in the ratio of spectral ordinates $(\lambda)$ and ISDR limit are investigated for 105 points mainly in the Marmara Region. The comparisons are conducted for five different local site conditions (ZA to ZE). The change in the ISDR limits is considerable, especially for the poor soil conditions. Moreover, the interaction of infill walls with the structural components has a direct influence on the ISDR limits.
\end{abstract}

\section{Keywords}

Story drift; Effective rigidity; Seismic codes; Earthquake.

Received: 23 September 2019; Accepted: 31 December 2019

ISSN: 2630-5763 (online) $\odot 2020$ Golden Light Publishing All rights reserved.

\section{Introduction}

Past damaging earthquakes revealed the significance of earthquake resistant structures not only to protect human life and property but also for the welfare of the society without any interruption. Unfortunately, Turkey, which is located in a very active seismic zone, has experienced numerous earthquake disasters resulting in thousands of loss of lives and extensive amount of financial losses. One of the main reasons for such huge losses is the presence of substandard structures in Turkey. Such buildings do not conform most of the earthquake resistant design principles and minimum requirements specified in current seismic codes [35]. Therefore, structural and non-structural damage is inevitable in substandard structures [6]. In order to design and construct earthquake-resistant structures, several seismic design codes were enforced in the history of Turkey. Owing to the progress in understanding the actual seismic behavior of structures through scientific research studies and experiences obtained after each 
damaging earthquake, seismic design codes have been developed and improved several times. The latest version of the Turkish Building Earthquake Code (TBEC, 2018) [1] is enforced starting from 2019. In this new version of the earthquake code, not only the existing code sections were improved, but also several new sections such as the seismic design of tall buildings, seismically isolated building, etc. were included. Besides the new requirements for structural systems, a coordinate based seismic hazard assessment can be conducted for each individual building, which is one of the significant differences compared to the preceding earthquake code. This has been achieved by the development of Earthquake Hazard Map of Turkey by AFAD [7]. The earthquake actions can be specified more accurately compared to the earthquake actions calculated by employing the earthquake zoning map, which is used in the former Turkish Earthquake Code (TEC, 2007) [2] for determining the earthquake forces.

With the implementation of the new version of the earthquake code (TBEC, 2018), several design requirements have been modified in comparison with the older version of the earthquake code (TEC, 2007). In this study, the modification of inter-story drift ratio (ISDR) limits specified for buildings is investigated. For this purpose, the requirements of each version of the earthquake code on ISDR limit is compared. The type of building (reinforced concrete (RC) or steel), the interaction of infill walls with the neighbouring structural components and the ratio of spectral ordinates at the fundamental period of the building for 72-year return period earthquake to 475 -year return period earthquake $(\lambda)$ are the critical parameters in defining ISDR limit by TBEC (2018). The $(\lambda)$ ratio is calculated for 105 points mainly in the Marmara Region, whose seismic parameters are obtained from the Earthquake Hazard Map of Turkey. The comparisons are conducted for five different local site conditions (ZA to ZE) to examine the effect of site conditions on the $(\lambda)$ ratio. Finally, the ISDR values of a 6-story RC building were calculated by employing both TEC (2007) and TBEC (2018). Then the calculated ISDR values were compared for the ISDR limits specified by the corresponding codes.

\section{Code requirements for ISDR}

Seismic design codes enforce structural engineers to limit the inter-story drifts of buildings to protect the non-structural components and to minimize the secondary effects of gravity loads. For this purpose, earthquake design codes limit the max ISDRs of building under seismic effects.

\subsection{ISDR limit of TEC (2007)}

The drift demand for each story is obtained by subtracting the successive floor displacements, which are obtained from structural analysis of the building under reduced earthquake forces as given by Eq. (1). The effective story drift is calculated with Eq. (2) by multiplying with the response reduction factor $(R)$. The max ISDR of the building is specified by calculating the maximum of the story drift to story height ratio. The max ISDR of buildings is limited by $2 \%$ as per TEC (2007) without considering any other criteria as in Eq. (3).

$$
\begin{aligned}
& \Delta_{i}=d_{i}-d_{i-1} \\
& \delta_{i}=R \Delta_{i} \\
& \max I S D R=\left(\frac{\delta_{i}}{h_{i}}\right)_{\max } \leq 0.02
\end{aligned}
$$

\subsection{ISDR limit of TBEC (2018)}

The drift demand for each story is obtained by subtracting the successive floor displacements, which are obtained from structural analysis of the building under reduced earthquake forces given by Eq. (1). The effective story drift is calculated with Eq. (4) by multiplying with the ratio of response reduction factor $(R)$ to importance factor $(I)$. Two different ISDR limits are specified for buildings depending on the interaction between the infill walls and the neighbouring structural components. If the infill walls are constructed adjacent to the structural components without any spacing inbetween, in other words, if the stiffness and strength of infill walls affect the seismic behaviour of the 
structural system, then the max ISDR limit is specified by Eq. (5). Otherwise, the ISDR limit is doubled as in Eq. (6) for the buildings whose structural components and infill walls are sufficiently separated such that the seismic response of the building is not affected by the infill walls. In Eq. (5) and (6), $\kappa=0.5$ for steel buildings and $\kappa=1.0$ for RC buildings. Therefore, the type of the building affects the ISDR limit considerably.

$\delta_{i}=\frac{R}{I} \Delta_{i}$

$\max I S D R=\left(\frac{\delta_{i}}{h_{i}}\right)_{\max } \leq \frac{0.008 \kappa}{\lambda} \mathrm{w} /$ interaction

$\max I S D R=\left(\frac{\delta_{i}}{h_{i}}\right)_{\max } \leq \frac{0.016 \kappa}{\lambda}$ w/o interaction (6)

where, $\lambda$ is the ratio of spectral ordinates at the fundamental period of the building of 72-year return period earthquake (DD-3) to 475-year return period earthquake (DD-2). Therefore, seismicity of the building location as well as its soil conditions affect the ISDR limit specified by TBEC (2018).

\section{3. $\lambda$ values for 105 points in Marmara region}

In order to investigate the effect of $\lambda$ on the code specified max ISDR limit, $\lambda$ values of 105 points in
Marmara Region were calculated for 5 different local site classes (ZA to ZE). The distribution of the inspected 105 points in Marmara Region is presented in Fig. 1.

Elastic spectral ordinates of each point are calculated by TBEC (2018). Spectral acceleration coefficients $S_{S}$ and $S_{1}$ are obtained from the Earthquake Hazard Map of Turkey for each individual point. The design spectral acceleration coefficients $S_{D S}$ and $S_{D 1}$ are determined by multiplying the spectral acceleration coefficients with local soil site coefficients given for 5 various site classes from ZA to ZE. The design spectral acceleration coefficients are employed to obtain the spectral ordinates of the inspected point for 5 different site classes. This procedure is repeated for the 72-year return period earthquake (DD-3) and the 475-year return period earthquake (DD-2). Finally, $\lambda$ is simply obtained by taking the ratio of elastic spectral ordinates at the fundamental period of the building for DD-3 earthquake to the one for DD-2 earthquake as shown in Fig. 2.

The variation of $\lambda$ for 5 different site classes is presented in Fig. 3 for different fundamental periods. In addition to the variation of $\lambda$ for each individual point, the minimum, maximum and mean variation for each site class are also presented. For each site condition, after a certain fundamental period, the variation of $\lambda$ is constant.

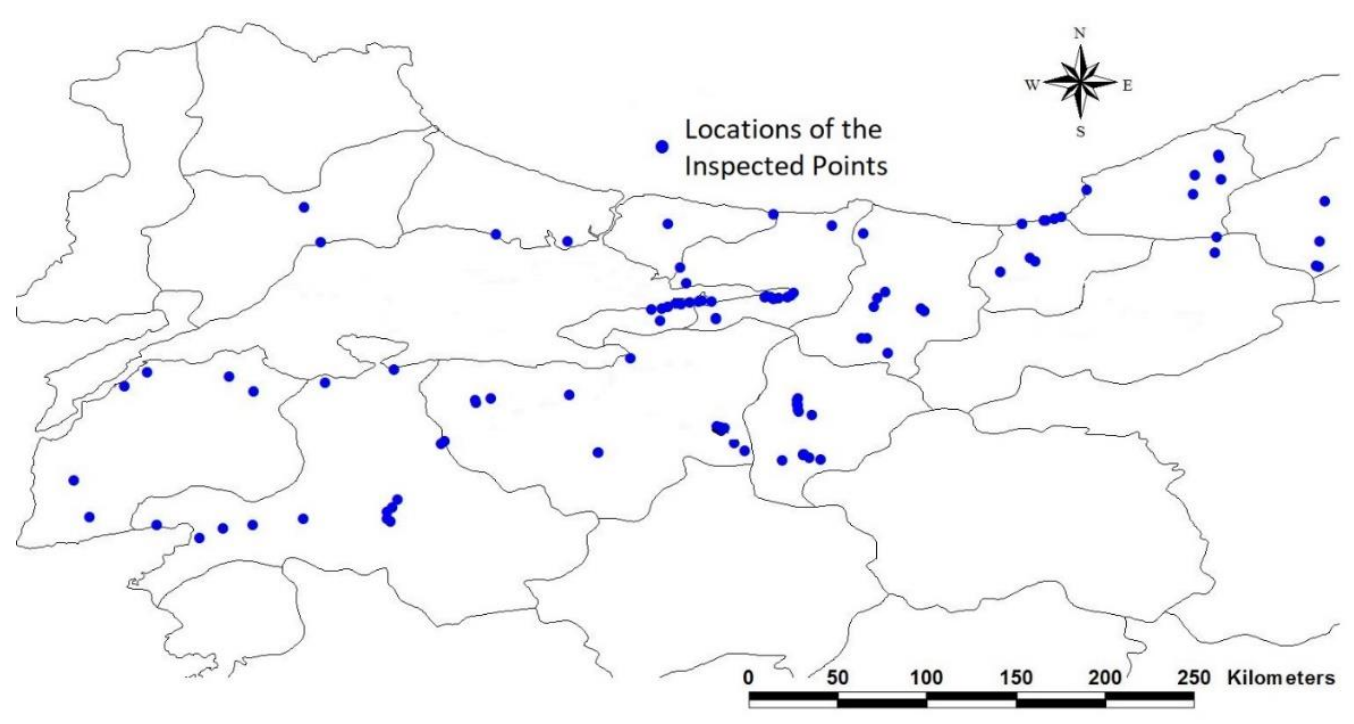

Fig. 1. Distribution of the inspected points in the Marmara Region 


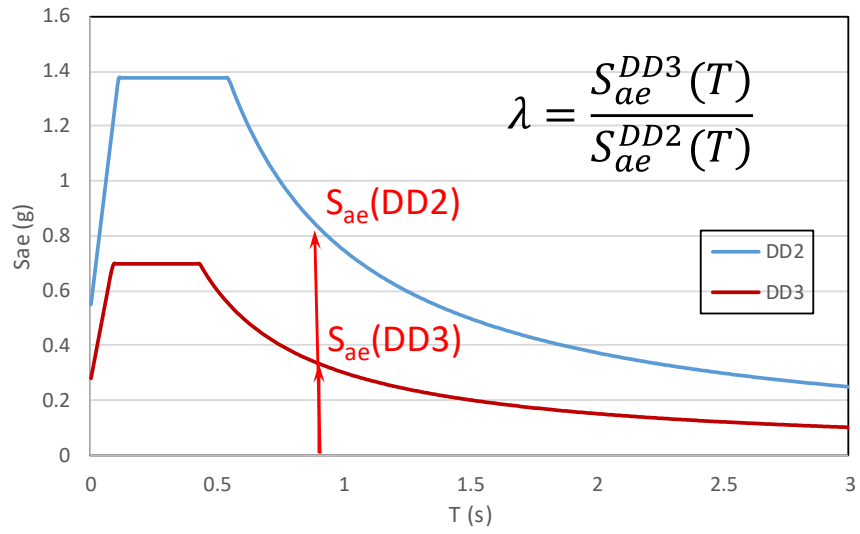

Fig. 2. Calculation of $\lambda$
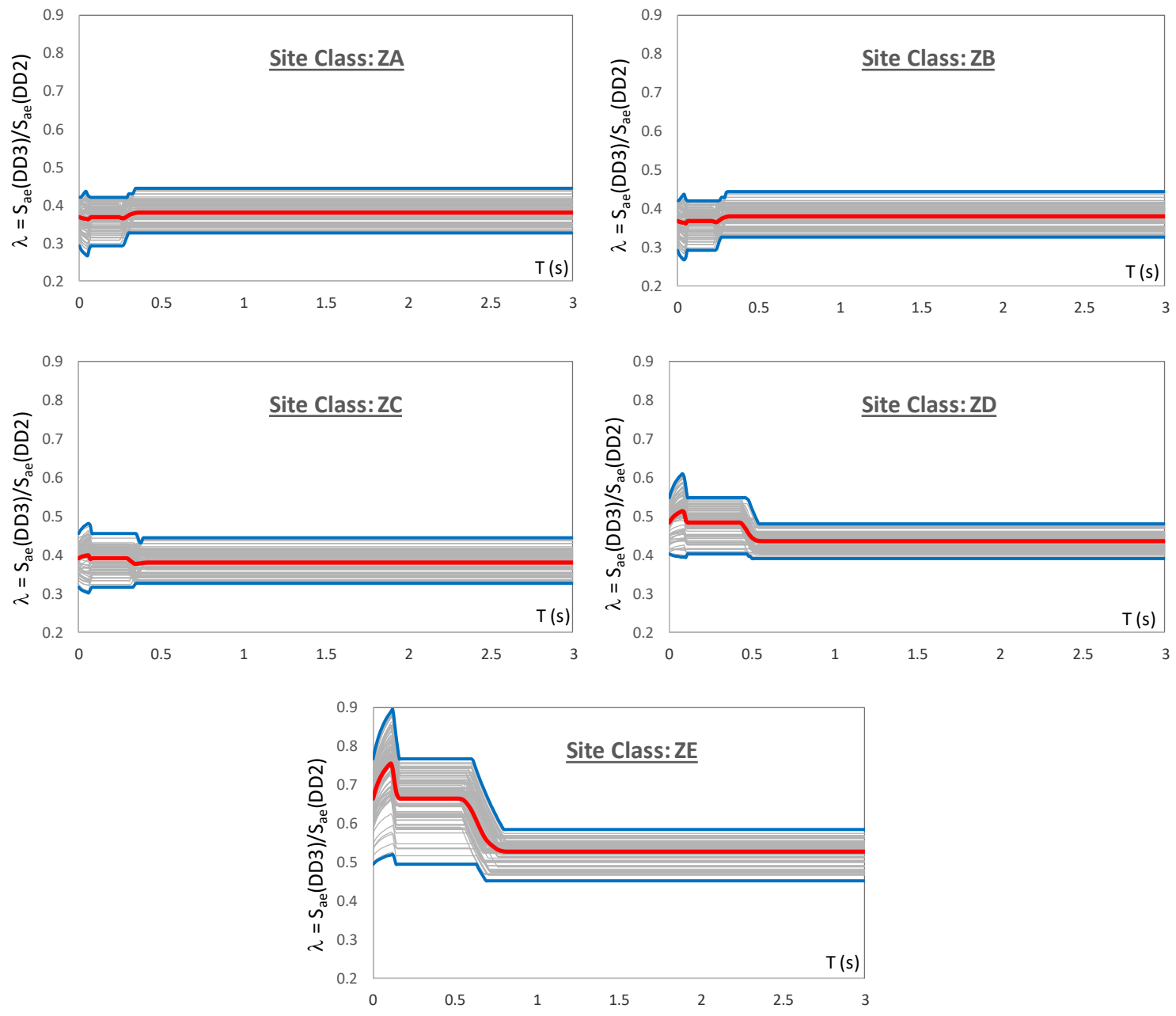

Fig. 3. Variation of $\lambda$ for 5 different site classes 
For relatively stiff to medium stiff site classes (ZA to $\mathrm{ZC}), \lambda$ generally varies between 0.3 to 0.5 . Whereas, as the soil condition gets worse, $\lambda$ becomes bigger especially for buildings with a low fundamental period. For very soft site conditions (ZE), the $\lambda$ value can reach to 0.8 depending on the fundamental period of the building. In Chapter 7 of the TEC (2007), which is the chapter entitled seismic performance assessment of existing buildings, the $\lambda$ value is approximated to be 0.5 without considering any parameter such as site conditions or fundamental period of the building. The mean variation of $\lambda$ values for each site class and TEC (2007) approximation for $\lambda$ value are compared in Fig. 4. TEC (2007) approximation for $\lambda$ overestimates the mean $\lambda$ values for $Z A, Z B, Z C$ and $Z D$ site classes. However, for the very soft site conditions (ZE), TEC (2007) underestimates the mean $\lambda$ values. This underestimation is much more for the fundamental period interval of $0-0.6$ seconds.

\section{Variation of ISDR limit for various parameters}

The $\lambda$ values obtained for the inspected 105 points were employed in calculating the ISDR limits given in Eqs. (5) and (6). Also, TEC (2007) approximation for $\lambda=0.5$ is considered to calculate the corresponding ISDR limit for comparison purposes. ISDR limits were determined for RC and steel buildings separately. Moreover, in order to investigate the effect of infill wall interaction with structural components on the ISDR limits, two cases were considered for each building type.

In the first case, the infill walls were considered to be adjacent to the neighboring structural components, whereas in the second case, it is assumed that a sufficient amount of gap is provided between the infill walls and structural components to prevent any interaction in-between, which is termed as isolated infill as shown in Fig. 5. Constant ISDR limit of $2 \%$ specified by TEC (2007) is presented in all graphs.

When infill walls are constructed adjacent to structural components of RC buildings, which is a very common practice in Turkey, for soft to very soft site conditions (ZD and ZE), depending on the fundamental period values, the ISDR limits are less than $2 \%$, which is the limiting ISDR specified in TEC (2007). For the medium to dense soil conditions (ZA, ZB, ZC), ISDR limit is determined to be slightly greater than $2 \%$. ISDR limits are considerably larger than $2 \%$, especially for good site conditions, when the infill walls are separated from the structural system with a sufficient gap. The ISDR limits for steel buildings is half of the ISDR limits for RC buildings. When infill walls are constructed adjacent to structural components of steel buildings, the ISDR limits were determined to be much less than $2 \%$. With this outcome, it is expected that the structural design of steel buildings will be mainly controlled by the ISDR limits specified by TBEC (2018).

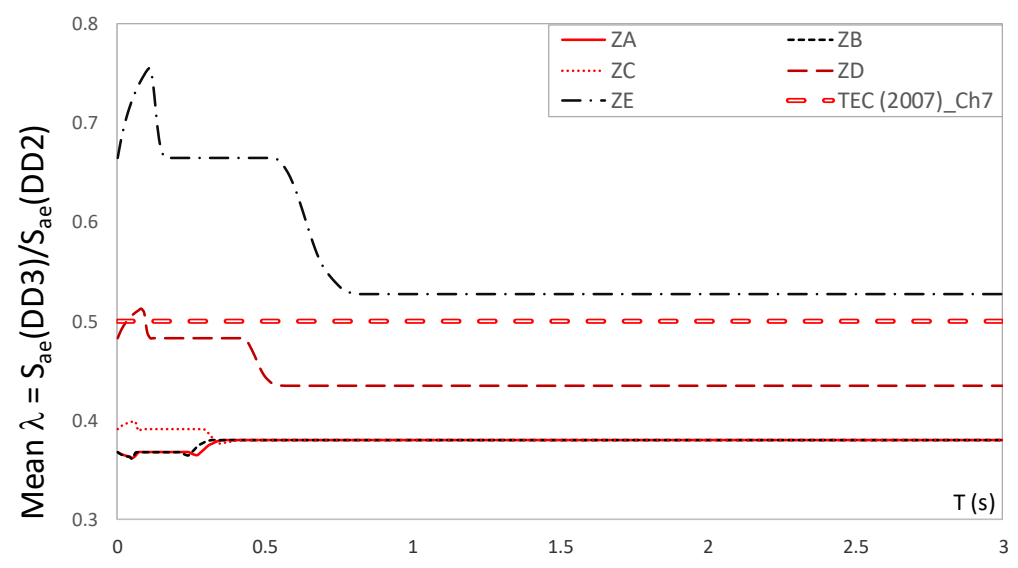

Fig. 4. Variation of mean $\lambda$ for 5 different site classes 

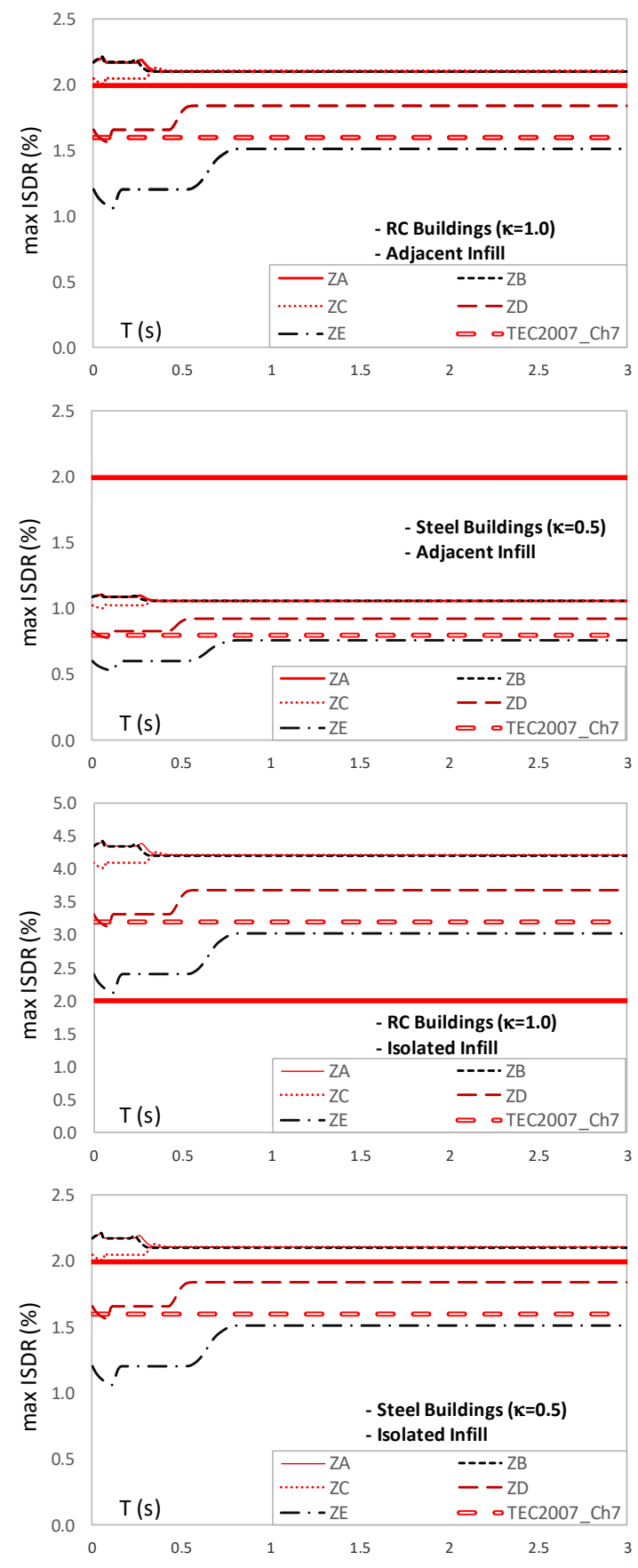

Fig. 5. Variation of ISDR limits for various cases

\section{ISDR of a 6-story RC building}

Although the ISDR limits specified by TEC (2007) and TBEC (2018) were compared in Fig. 5, the calculation of ISDR by the two codes is not comparable. First of all, earthquake forces determined by the two codes expected to vary due to the differences in the design spectral accelerations, local site class definitions, seismic hazard maps employed. Other than the variation in the seismic actions, in the seismic design of RC buildings, TBEC (2018) take the effective section rigidities into account to consider cracking and section yielding, whereas TEC (2007) considers the gross sectional properties.

Therefore, for the same RC building, even under the same earthquake forces, TBEC (2018) results in more flexible structural system and consequently increased lateral displacements are determined compared to TEC (2007). Therefore, larger ISDR values will be calculated with TBEC (2018).

The variation in the ISDR demands and the corresponding limit specified for two earthquake codes were investigated with an analytical model of a 6-story RC framed building. The selected 6-story $\mathrm{RC}$ building is the first design example presented both in the design examples books presented for TEC (2007) [8] and TBEC (2018) [9]. The building is assumed to be located in İstanbul with the coordinates of $40.960^{\circ} \mathrm{N}$ and $28.825^{\circ} \mathrm{E}$. The structural system of the building is assumed to have a high ductility level. Therefore, the response reduction factor $(\mathrm{R})$ of the building is 8.0. The building is in the $1^{\text {st }}$ Seismic Zone and its local site class is specified as Z3 according to TEC (2007). Whereas, its local site class is specified as ZD according to TBEC (2018). The design spectral acceleration specified by both earthquake codes is presented in Fig.6.

The selected 6-story framed building is a residential building with a height of $3.5 \mathrm{~m}$ in the ground story, whereas the height of the normal stories is $3 \mathrm{~m}$. As shown in Fig. 7, the structural system has a symmetrical floor plan and it does not have any structural irregularity specified in both earthquake design codes. The analytical model of the building was developed in SAP2000 [10]. There are some differences in the mass calculation of the selected building in the design examples books of TEC (2007) and TBEC (2018). 


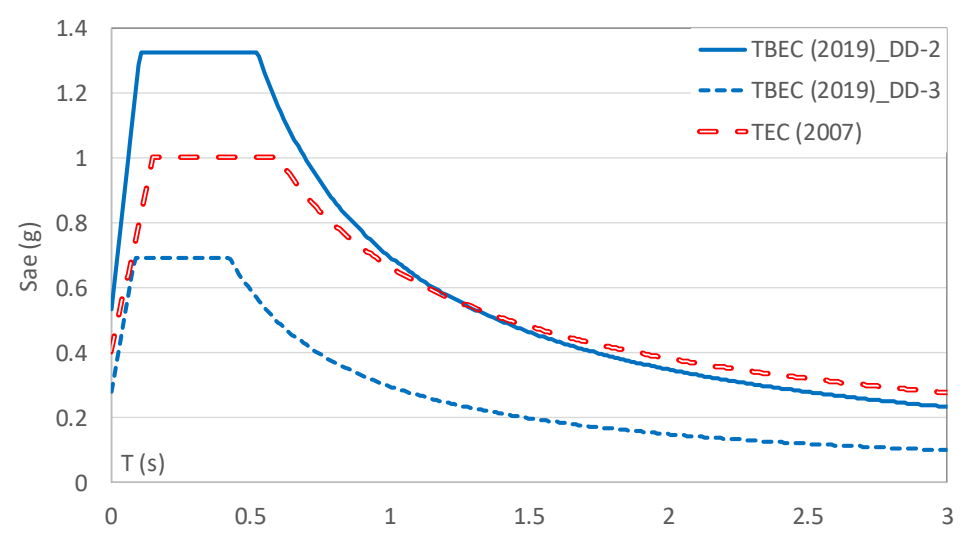

Fig. 6. Design acceleration spectrum for the 6-story RC building

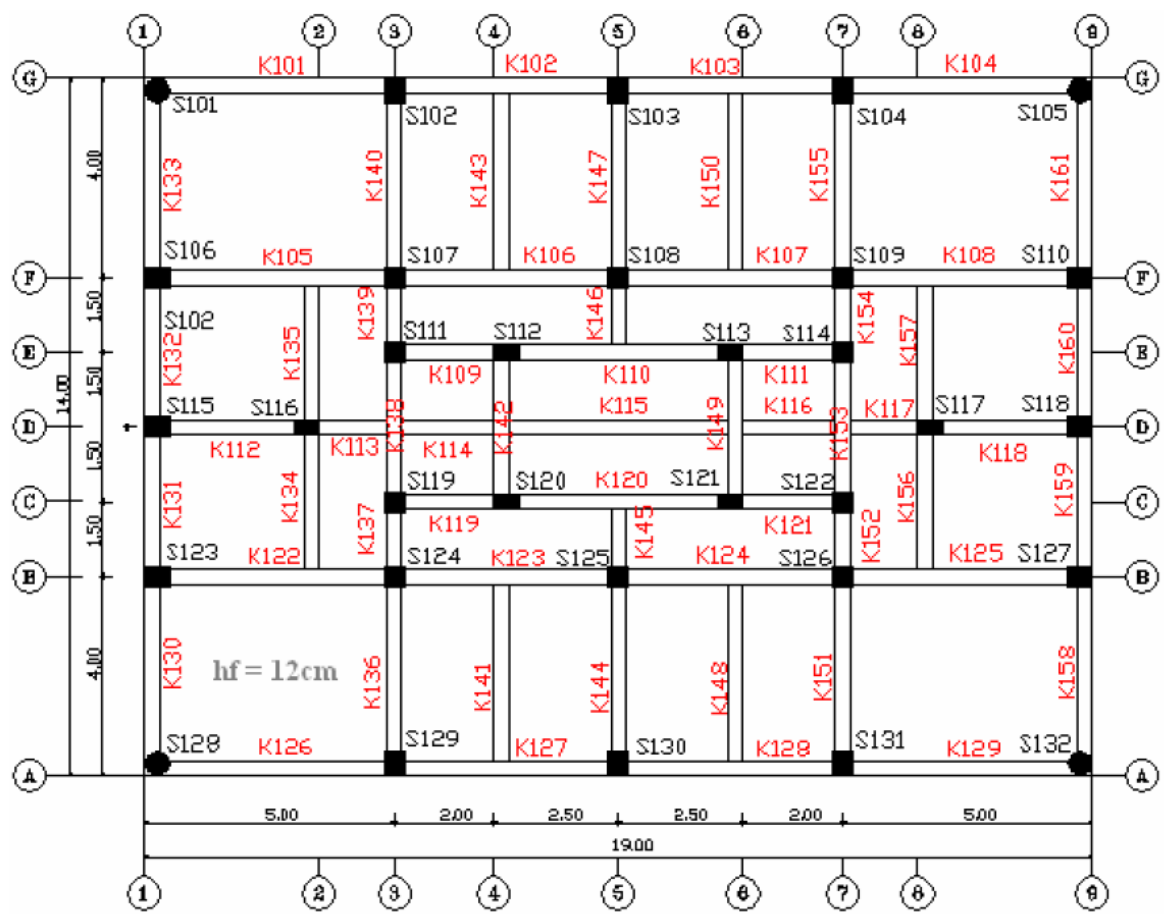

Fig. 7. Floor plan of the 6-story RC framed building [8]

To be consistent in the earthquake force calculation for both codes, the mass calculation presented in the design examples of TBEC (2018) was adopted in the developed analytical model. The total mass of the building is assumed to be 2110 tons. As shown in Fig. 8, two analytical models were developed to perform structural analysis for both gross sectional properties and effective sectional properties, which were obtained from TBEC (2018). Accordingly, flexural rigidity of the column and beam sections were modified by 0.7 and 0.35 , respectively.

First, modal analyses were conducted to obtain the modal properties of the building with two different section rigidities. The modal properties of the building for the two principal axes are presented in Table 1. Modal properties of the building in both principal axes are very similar to each other owing to the symmetry in the structural system. 


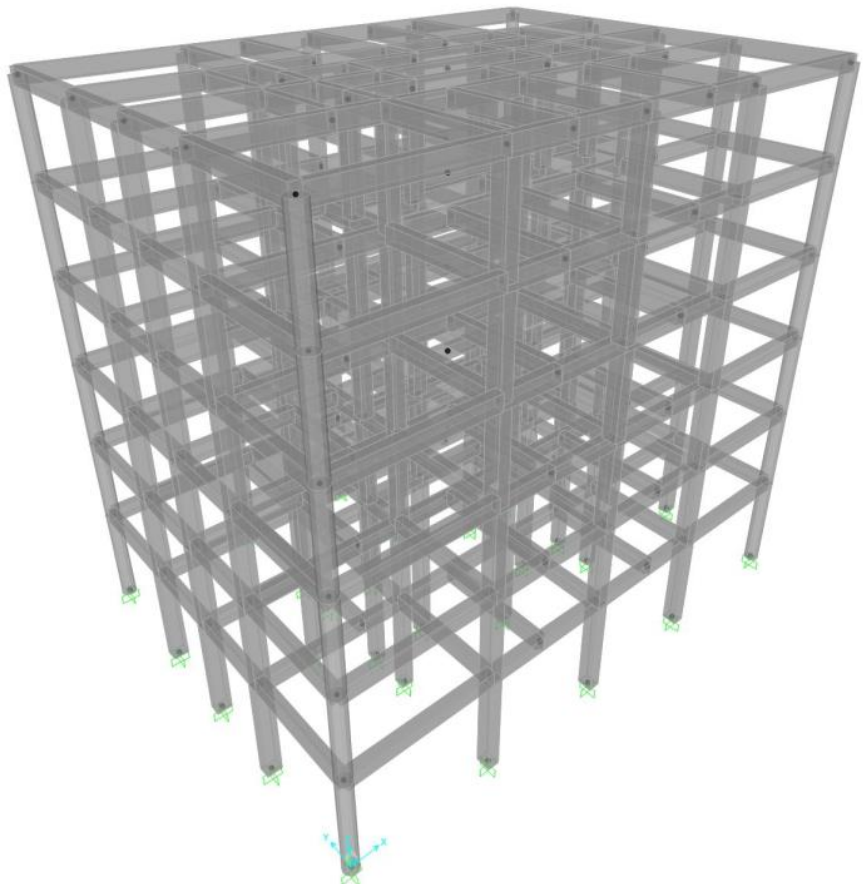

Fig. 8. Analytical model of the selected 6-story RC framed building

Table 1. Modal properties of the 6-story RC building with EI $I_{\text {eff }}$ and $\mathrm{EI}_{\text {gross }}$

\begin{tabular}{|c|c|c|c|c|c|c|c|c|}
\hline \multirow[b]{2}{*}{$\begin{array}{l}\text { Section } \\
\text { Rigidity }\end{array}$} & \multicolumn{4}{|c|}{ X-Direction } & \multicolumn{4}{|c|}{ Y-Direction } \\
\hline & $\begin{array}{c}\text { Mass } \\
\text { Participation } \\
(\%)\end{array}$ & $\begin{array}{l}\text { Period } \\
\text { (s) }\end{array}$ & $\begin{array}{l}\text { Modal } \\
\text { Mass } \\
\text { (tons) }\end{array}$ & $\begin{array}{l}\text { Modal } \\
\text { Stiffness } \\
(\mathrm{kN} / \mathrm{m})\end{array}$ & $\begin{array}{c}\text { Mass } \\
\text { Participation } \\
(\%)\end{array}$ & $\begin{array}{l}\text { Period } \\
\text { (s) }\end{array}$ & $\begin{array}{l}\text { Modal } \\
\text { Mass } \\
\text { (tons) }\end{array}$ & $\begin{array}{c}\text { Modal } \\
\text { Stiffness } \\
(\mathrm{kN} / \mathrm{m})\end{array}$ \\
\hline EI $_{\text {gross }}$ & 86.6 & 0.719 & 1 & 76.4 & 86.1 & 0.731 & 1 & 73.9 \\
\hline $\mathrm{EI}_{\mathrm{eff}}$ & 84.7 & 0.992 & 1 & 40.1 & 85.4 & 0.987 & 1 & 40.5 \\
\hline
\end{tabular}

Although the mass participation ratio of both models does not change considerably, there is a $35 \%$ increase in the fundamental period of the building when effective sectional properties are concerned. Modal properties are obtained for the mass normalized mod shapes. The modal stiffness of the fundamental vibration mode for the analytical model with effective sectional rigidities in both principal axes is almost half of the modal stiffness calculated with gross sectional properties. This outcome is considered to be the evidence for achieving a less stiff structural model when the effective rigidities are considered.

Equivalent earthquake loads were calculated for each principal axes of the building. Lateral loads calculated in Table 2 and Table 3 were applied to the floor mass center as well as to the points defined by shifting it $\pm 5 \%$ of the floor plan length in the perpendicular direction to the earthquake direction considered in order to account for the additional eccentricity effects. ISDR demands at each story were calculated by conducting the structural analysis under the effect of seismic loading for both codes. Although the equivalent earthquake load determined by TBEC (2018) is less than the one for TEC (2007) due to differences in spectral ordinates and seismic hazard calculations, the ISDR demands calculated by TBEC (2018) are more than 50\% greater than the ISDR demands calculated by TEC (2007) on average (Table 2 and Table 3). 
Table 2. Equivalent earthquake load and ISDR demands with TBEC (2018)

\begin{tabular}{cccccccc}
\hline \multicolumn{7}{c}{ X-Direction } \\
\hline Story No. & $\mathrm{h}_{\mathrm{i}}(\mathrm{m})$ & $\mathrm{m}_{\mathrm{i}}(\mathrm{t})$ & $\mathrm{F}_{\mathrm{X}}(\mathrm{kN})$ & $\mathrm{u}_{\mathrm{i}}{ }^{(\mathrm{X})}(\mathrm{mm})$ & $\Delta_{\mathrm{i}}{ }^{(\mathrm{X})}(\mathrm{mm})$ & $\delta_{\mathrm{i}}=\mathrm{R} / \mathrm{I} \cdot \Delta_{\mathrm{i}}{ }^{(\mathrm{X})}(\mathrm{mm})$ & $\delta_{\mathrm{i}}{ }^{(\mathrm{X})} / \mathrm{h}_{\mathrm{i}}$ \\
\hline 6 & 3 & 260.7 & 457.2 & 36.90 & 2.71 & 21.67 & 0.0072 \\
5 & 3 & 369.2 & 445.1 & 34.19 & 4.66 & 37.27 & 0.0124 \\
4 & 3 & 369.2 & 358.9 & 29.53 & 6.39 & 51.09 & 0.0170 \\
3 & 3 & 369.2 & 272.8 & 23.14 & 7.65 & 61.20 & 0.0204 \\
2 & 3 & 369.2 & 186.6 & 15.49 & 8.26 & 66.09 & 0.0220 \\
1 & 3.5 & 372.8 & 101.5 & 7.23 & 7.23 & 57.86 & 0.0165 \\
\hline Story No. & $\mathrm{h}_{\mathrm{i}}(\mathrm{m})$ & $\mathrm{m}_{\mathrm{i}}(\mathrm{t})$ & $\mathrm{F}_{\mathrm{Y}}(\mathrm{kN})$ & $\mathrm{u}_{\mathrm{i}}^{(\mathrm{Y})}(\mathrm{mm})$ & $\Delta_{\mathrm{i}}^{(\mathrm{Y})}(\mathrm{mm})$ & $\delta_{\mathrm{i}}=\mathrm{R} / \mathrm{I} \cdot \Delta_{\mathrm{i}}^{(\mathrm{Y})}(\mathrm{mm})$ & $\delta_{\mathrm{i}}^{(\mathrm{Y})} / \mathrm{h}_{\mathrm{i}}$ \\
\hline 6 & 3 & 260.7 & 457.2 & 38.68 & 2.79 & 22.32 & 0.0074 \\
5 & 3 & 369.2 & 445.1 & 35.89 & 4.81 & 38.45 & 0.0128 \\
4 & 3 & 369.2 & 358.9 & 31.08 & 6.58 & 52.63 & 0.0175 \\
3 & 3 & 369.2 & 272.8 & 24.50 & 7.89 & 63.11 & 0.0210 \\
2 & 3 & 369.2 & 186.6 & 16.61 & 8.63 & 69.04 & 0.0230 \\
1 & 3.5 & 372.8 & 101.5 & 7.98 & 7.98 & 63.86 & 0.0182 \\
\hline
\end{tabular}

Table 3. Equivalent earthquake load and ISDR demands with TEC (2007)

\begin{tabular}{cccccccc}
\hline \multicolumn{7}{c}{ X-Direction } \\
\hline Story No. & $\mathrm{h}_{\mathrm{i}}(\mathrm{m})$ & $\mathrm{m}_{\mathrm{i}}(\mathrm{t})$ & $\mathrm{F}_{\mathrm{x}}(\mathrm{kN})$ & $\mathrm{d}_{\mathrm{i} \text {-max }}(\mathrm{mm})$ & $\Delta_{\mathrm{i} \text {-max }}(\mathrm{mm})$ & $\delta_{\mathrm{i}-\max }=\mathrm{R} \Delta_{\mathrm{i}}(\mathrm{mm})$ & $\delta_{\mathrm{i} \text {-max }} / \mathrm{h}_{\mathrm{i}}$ \\
\hline 6 & 3 & 260.7 & 561.7 & 23.56 & 1.66 & 13.28 & 0.0044 \\
5 & 3 & 369.2 & 546.9 & 21.90 & 2.88 & 23.04 & 0.0077 \\
4 & 3 & 369.2 & 441.1 & 19.02 & 3.94 & 31.52 & 0.0105 \\
3 & 3 & 369.2 & 335.2 & 15.08 & 4.71 & 37.68 & 0.0126 \\
2 & 3 & 369.2 & 229.4 & 10.37 & 5.20 & 41.60 & 0.0139 \\
1 & 3.5 & 372.8 & 124.7 & 5.17 & 5.17 & 41.36 & 0.0118 \\
\hline Story No. & $\mathrm{h}_{\mathrm{i}}(\mathrm{m})$ & $\mathrm{m}_{\mathrm{i}}(\mathrm{t})$ & $\mathrm{F}_{\mathrm{Y}}(\mathrm{kN})$ & $\mathrm{d}_{\mathrm{i} \text {-max }}(\mathrm{mm})$ & $\Delta_{\mathrm{i}-\mathrm{max}}(\mathrm{mm})$ & $\delta_{\mathrm{i}-\mathrm{max}}=\mathrm{R} \Delta_{\mathrm{i}}(\mathrm{mm})$ & $\delta_{\mathrm{i}-\max } / \mathrm{h}_{\mathrm{i}}$ \\
\hline 6 & 3 & 260.7 & 554.3 & 25.33 & 1.75 & 14.00 & 0.0047 \\
5 & 3 & 369.2 & 539.7 & 23.58 & 3.06 & 24.48 & 0.0082 \\
4 & 3 & 369.2 & 435.3 & 20.52 & 4.17 & 33.36 & 0.0111 \\
3 & 3 & 369.2 & 330.8 & 16.35 & 5.00 & 40.00 & 0.0133 \\
2 & 3 & 369.2 & 226.3 & 11.35 & 5.56 & 44.48 & 0.0148 \\
1 & 3.5 & 372.8 & 123.1 & 5.79 & 5.79 & 46.32 & 0.0132 \\
\hline
\end{tabular}


This outcome is attributed to the effective flexural rigidities employed by TBEC (2018), while gross sectional properties were used by TEC (2007).

The ISDR limit for the building was calculated based on the Eqns. (5) and (6) for two cases, which are adjacent infill walls and isolated infill walls, respectively. Since the fundamental period of the building in both principal axes is very close to each other, the same $\lambda$ values were calculated. Therefore, the same ISDR limits were determined for both axes as shown in Table 4.

The variation of ISDR demands along the story height is presented together with the ISDR limits in Fig. 9 and Fig. 10. According to TEC (2007) results, all the ISDR demands are less than $2 \%$, which is the ISDR limit as per TEC (2007) as shown in Fig. 9. This indicates that the investigated 6-story RC building is acceptable in terms of the ISDR criteria.
On the other hand, the ISDR demands calculated by TBEC (2018) at the $2^{\text {nd }}$ and $3^{\text {rd }}$ story exceed the ISDR limit specified for the building with adjacent infill walls (Fig. 10). Therefore, the investigated building with adjacent infill walls is not acceptable. If the structural engineer wants to design this building with adjacent infill walls, he/she should increase the stiffness of the structural system to reduce the ISDR demands. Otherwise, the infill walls should be separated from the structural components with sufficient gap in-between. Both design and construction practice in Turkey is not familiar with the concept of isolated infill walls. In such a case, additional details should be developed in isolating the infill walls from the structural components in order to prevent their out-of-plane failure and fulfill thermal and sound insulation.

Table 4. ISDR limit calculation by TBEC (2018)

\begin{tabular}{ccc}
\hline & X-Direction & Y-Direction \\
\hline $\mathrm{T}(\mathrm{s})$ & 0.992 & 0.987 \\
$S_{a e}^{D D-3}(T)(\mathrm{g})$ & 0.298 & 0.300 \\
$S_{a e}^{D D-2}(T)(\mathrm{g})$ & 0.700 & 0.704 \\
$\lambda$ & 0.426 & 0.426 \\
Max ISDR (adjacent infill) & $\frac{0.008 \cdot \kappa}{\lambda}=\frac{0.008 \cdot 1.0}{0.426}=0.0188$ \\
Max ISDR (isolated infill) & $\frac{0.016 \cdot \kappa}{\lambda}=\frac{0.016 \cdot 1.0}{0.426}=0.0376$ & \\
\hline
\end{tabular}

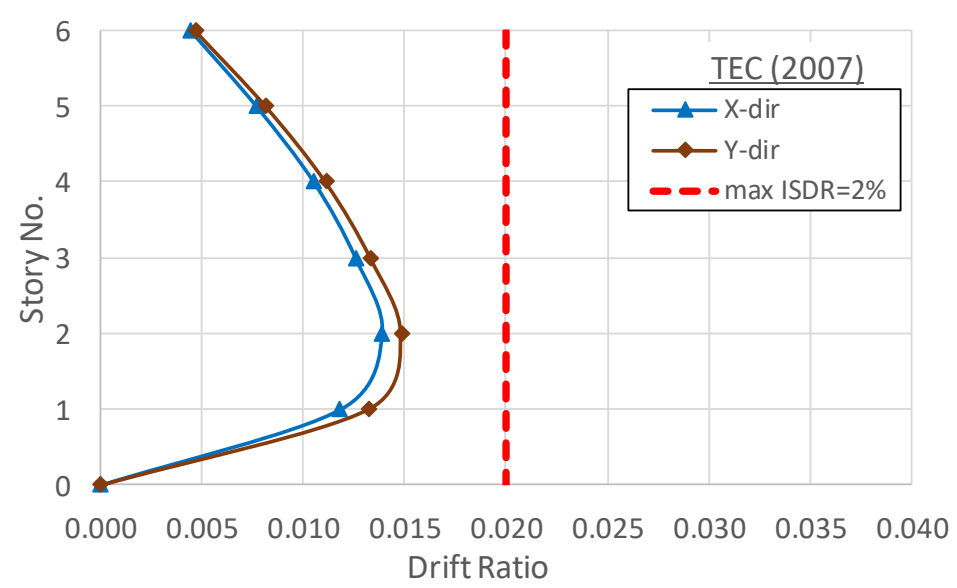

Fig. 9 ISDR and limits of the 6-story RC building according to TEC (2007) 


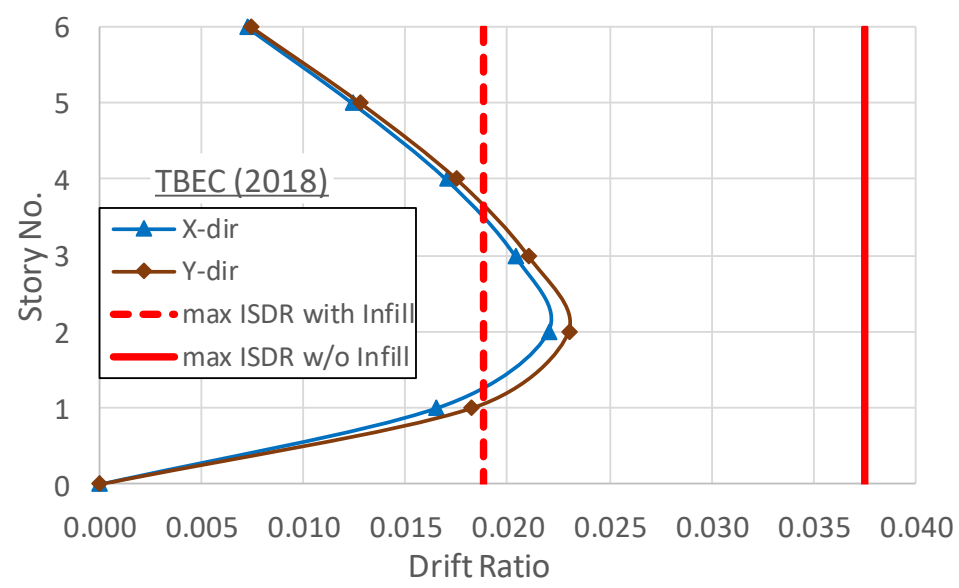

Fig. 10 ISDR and limits of the 6-story RC building according to TBEC (2018)

\section{Summary and conclusions}

A new version of Turkish Building Earthquake Code (TBEC, 2018) is in act starting from 2019 by replacing the former version of the Turkish Earthquake Code (TEC, 2007). One of the significant changes in TBEC (2018) is the definition of the inter-story drift ratio limit. The ISDR demand is limited by $2 \%$ as per TEC (2007) without considering any other criteria. However, with the implementation of the new version of the seismic code, ISDR limit is modified by considering several parameters. The type of building ( $\mathrm{RC}$ or steel), the interaction of infill walls with the neighbouring structural components and the ratio of spectral ordinates at the fundamental period of the building of 72-year return period earthquake to 475 -year return period earthquake $(\lambda)$ are the three important factors in the definition of ISDR limit. Therefore, seismicity of the building site as well as its soil conditions affect the ISDR limit. Besides these parameters, effective rigidities of RC members should be adopted in TBEC (2018) instead of gross sectional properties, which are considered in TEC (2007) for the new design. This will reduce the building stiffness and hence result in increased displacements with the new code requirements. Change in ISDR limits specified by the two versions of the earthquake code is examined for a 6-story RC building. Moreover, the variation of the ratio of spectral ordinates $(\lambda)$ and hence the ISDR limit is investigated for 105 points mainly in
Marmara Region, whose seismic parameters are obtained from Earthquake Hazard Map of Turkey. The comparisons are conducted for five different local site conditions (ZA to ZE). Based on this study, the following conclusions can be drawn:

1. The type of the building affects the ISDR limit specified by TBEC (2018) considerably. The ISDR limit for steel buildings is half of the ISDR limit for RC buildings. On the other hand, considering the effective flexural rigidities for the RC sections increases the displacement demands of RC buildings with the implementation of TBEC (2018).

2. TBEC (2018) enforces to reduce the ISDR limit to its half when the infill walls interact with the neighboring structural components. This requirement enforces the structural engineer to design much stiffer buildings. Otherwise, the infill walls should be separated from the structural components with sufficient gap inbetween. Separation of infill walls will require additional details to prevent their out-of-plane failure and to fulfill thermal and sound insulation.

3. Smaller ISDR limits were calculated for buildings constructed at soft soil sites especially if the fundamental period of the building is in the range of 0-0.6 seconds. 


\section{Declaration of conflicting interests}

The author(s) declared no potential conflicts of interest with respect to the research, authorship, and/or publication of this article.

\section{References}

[1] Turkish Building Earthquake Code (TBEC) (2018) Specification for buildings to be built in seismic zones, Disaster and Emergency Management Presidency, Government of Republic of Turkey, Ankara, Turkey.

[2] Turkish Earthquake Code (TEC) (2007) Specification for buildings to be built in seismic zones, Ministry of Public Works and Settlement, Government of the Republic of Turkey, Ankara, Turkey.

[3] Yurdakul, O., Avsar, O (2016) Strengthening of substandard reinforced concrete beam-column joints by external post-tension rods. Engineering Structures 107: 9-22.

[4] Tunaboyu, O, Avşar, Ö (2017) Seismic repair of captive-column damage with CFRPS in substandard RC frames. Structural Engineering and Mechanics 61(1): 1-13.
[5] Duran B, Tunaboyu O, Kaplan O, Avşar Ö (2018) Effectiveness of repairing stages with CFRPs on the seismic performance of damaged RC frames. Structural Engineering and Mechanics 67(3): 233244.

[6] Y1lmaz, N., Avşar, Ö (2013) Structural damages of the May 19, 2011, Kütahya-Simav Earthquake in Turkey. Natural Hazards 69(1): 981-1001.

[7] AFAD (2018) Earthquake Hazard Map of Turkey. https://tdth.afad.gov.tr/

[8] Deprem Bölgelerinde Yapılacak Binalar Hakkında Yönetmelik Açıklamalar ve Örnekler Kitabı. TC Bayındırlık ve İskan Bakanlığı, Ankara, 2009 (in Turkish).

[9] Türkiye Bina Deprem Yönetmeliği Örnekler Kitabı. TC İçişleri Bakanlığı, Afet ve Acil Durum Yönetimi Başkanlığı, Ankara, 2018 (in Turkish).

[10] SAP2000 Version 15.1.0. Structural analysis program. Computers and Structures Inc., 2000, Berkeley. 